Tbilisi, Georgia

ketramshvili@yahoo.com

Original research article

Received: March 5th 2013

Accepted: February 15th 2014

\title{
FOR THE TYPOLOGY OF ENGRAVED DEPICTIONS OF "FANTASTIC" ANIMALS ON COLCHIAN AXES
}

\begin{abstract}
One of the most important elements of decoration of Colchian-Kobanian bronze is a depiction of fantastic animal or dog. The article refers of the engraved depictions of dogs on the Colchian axes found in Georgia. The depictions are divided into two groups: The first group contains examples that are implemented in the naturalistic - linear manner. The examples of second group are very stylized and schematic. The ornamented axes bear together both depictions - dogs and geometric figures. Dogs are represented in profile, with their jaws open and ears and tail upward. Notwithstanding of some variations they compose one artistical group with their stylistical features.

The difference of depictions of dogs in groups 1 and 2 was caused by the alternation of artistic manner during the time. It was changed from natural to schematic; from realistic to geometric; from decorative to ornamental. The depictions with concrete shape were replaced by syncretical and polymorphic figures and the definition of dog was transformed to the depiction of Fantastic animal.
\end{abstract}

Keywords: Colchian axes, Colchian-Kobanian bronze, fantastic animal.

Among the archaeological cultures discovered in the Caucasus, the Colchis-Koban circle monuments always attracted particular attention. There are a number of scientific works created around the issues of their artistic decoration (Kuftin B. 1949; Koridze D. 1965; Amiranashvili Sh. 1970; Mikeladze T. 1974; Lortkipanidze Ot. 2001; Pantskhava L. 1988).

The existence of analog images on European monuments urged us to study and document the images of "Fantastic" animals engraved on Georgian and Caucasian bronze items in general (Sulava N. 2010; Ramishvili K. 2010, 2011; Sulava N. and Ramishvili K. 2011), which in our opinion opens up perspectives for further research (in terms of early contacts). However in the given work, we shall only discuss the graphical images of "fantastic" an- imals and wolf-dogs presented on Colchis axes found on the territory of Georgia, from typological and stylistically-compositional points of view.

A number of considerations have been made about the origin of "fantastic" animals in scientific literature. P. Uvarova distinguishes a dragon or a "fantastic" animal, a wolf or a tiger among the animals represented on Colchis axes (Uvarova P. 1900: 67); I. Meshchaninov believes that the "fantastic" animals engraved on the Koban axes are wolf-dogs, which represent the Iberian totem (Meshchaninov I. 1925: 250); According to Sh. Amiranashvili, this animal is a wolf or a dog and represents the Colchis totem (Amiranashvili Sh. 1950: 42-43); A. Miller believed that the "fantastic" animal portrayed on the axes is definitely a dog, a wolf-dog or a wild dog (Miller A. 1922: 316-318); El. Virsaladze related 


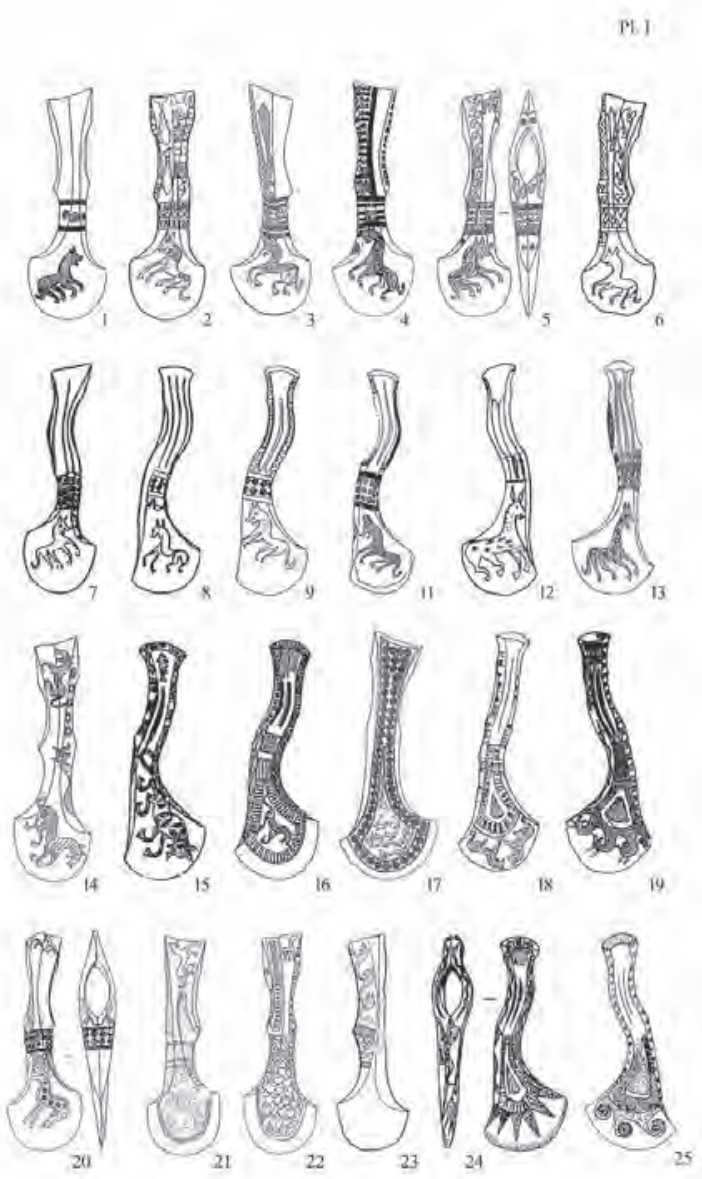

Pl. I- First group:

1. Khikhadziri, hoard, 8th-7th cc BC (Kakhidze A. and Mamuladze Sh. 1993: 27- 34, pl. V); 2. Tlia, grave 52, 8 th-7 th cc.BC (Pantskava L. 1988: 76, pl. XVIII, 3; Tekhov B.1980: 14, 20, pl. 46, fig. 6); 3. Eshera, grave 4, Late Bronze Age (Kuftin B. 1949:192, pic.37); 4. Khikhadziri, hoard, 8th-7th cc BC (Kakhidze A. and Mamuladze Sh. 1993: $28-34$, pl. VII); 5. Oni, 8th-6th cc BC (Unterwegs zum goldenen Vlies 1995: 108, pl. 93); 6. Tsiteli Shukura, grave 94, 8th-6 th cc BC (Trapsh M. 1969: 144, pl. XV, 2); 7. Nikortsminda, hoard, 8 th-7 th cc.BC (Pantskava L. 1988: 69; Koridze D. 1965 : 36, pic.29, fig. 2); 8. Surmushi, hoard, 8 th-7 th cc.BC (Pantskava L. 1988: 69; Koridze D. 1965: 35, pic.28); 9. Dgvaba, grave 2, 7th-6th cc.BC (Mikeladze T. 1995: 14-18; Mikeladze T., Migdisova N., Papuashvili R., and Chubinishvili N. 1995: pl. 54); 10. Zakaani, 8 th-7 th cc.BC (Ramishvili K. 2010: 84, pl. I, 10); 11. Samtavro, grave 121, 8 th-7 th cc.BC (Abramishvili R. 1957: 132; Abramishvili R. 1961: pl. XIV, 1); 12. Natsargora, grave 319, 8 th-7 th cc.BC (Ramishvili A. 2003: 43, pl. II, 963); 13. Anukhva, 8 th-7 th cc.BC (Domanski Y. 1984: 11, pic.3); 14. Tlia, grave 282,8 th-7 th cc.BC, (Pantskava L. 1988: 70-71; Tekhov 1981: 6, pl. 82, fig. 1); 15. Tlia, grave 414, 8 th c.BC, (Tekhov B. 2002: 43, 185, pl. 87, pic. 1); 16. Narekvavi, grave 53, 7th-6 th cc BC (Apakidze A., Nikolaishvili V., Kipiani G. Sikharulidze A., Giunashvili G., Gavasheli E., Glonti N. and Kapanadze M. 2005: 32, pl. XV, 597); 17. Svaneti, Late Bronze Age (Chartolani Sh. 1977: 50, pl. XXIII-3); 18. Tlia, grave 308, 7th-6 th cc BC (Pantskava L. 1988: 64; Tekhov B. 1981: 6, 22, pl. 87, fig. 1); 19. Kutaisi, 8 th c. BC (Pantskava L. 1988: 71, pl. XIII, 1); 20. Tlia, grave 50, 8 th-7 th cc. BC (Pantskava L. 1988: 80; Tekhov B. 1980: 14, 20, pl. 45, pic. II, fig. 4); 21. Lukhvano, hoard, 8 th-7 th cc. BC (Pantskava L. 1988: 64; Domanski Y. 1984: pic. 2); 22. Etseri, Late Bronze Age (Chartolani Sh. 1977: 51, pl. XXV, 1); 23. Tlia, grave 101, 7 th-6 th cc. BC (Pantskava L. 1988: 64; Tekhov B. 1980: 26-27, pl. 66, fig.1); 24. Mukhurcha, 8 th-7 th cc. BC (Apakidze J. 1991: 73, 116, pl. CXIV, 2). 
these animals to the mythical dog-pet ("kursha") well known in Georgian folklore (Virsaladze E. 1964: 72, 97); As for V. Bardavelidze, he considered the majority of "fantastic" animals portrayed on Colchis axes as dogs (Bardavelidze V. 1957: 29-30; 47-53); L. Pantskhava also describes such images as dogs (Pantskhava L. 1988; 27, 48). As we see, the majority of researchers considered the animals engraved on Colchis axes to be dogs. We also share their consideration and distinguish this animal to be a dog; however, we believe that later, for a number of reasons, it took on the appearance of a "fantastic" animal.

The axes with the images of dogs discovered in Georgia mainly come from burial complexes, treasure, and some are accidental acquisitions. All of this material can be divided into two groups, according to the manner of depicting images. Out of them, we unified 44 samples into the $1^{\text {st }}$ group, and 41 into the $2^{\text {nd }}$. (85 pieces in total, which represents $80 \%$ of all analog items discovered in Caucasus).

In the $1^{\text {st }}$ group we placed the graphical images of dogs or their heads, which are always presented in profile. Through modeling a pliable continuous line on a flat surface, a more or less realistic figure is received. Apparently, first the body contour was outlined, and then afterwards it was decorated with different faces (Kakhidze A. and Mamuladze Sh. 1993: 27-34). The dog figures in the $1^{\text {st }}$ group are proportional, they have a relatively static, calm pose and the works are executed in a natural-linear manner (pl. I, fig: 1-23).

We have divided the $1^{\text {st }}$ group images into two sub-groups according to the manner of depicting, out of which the $1^{\text {st }}$ subgroup of group 1 unites the figures of dogs, which have moderately open gullets, pricked up ears, a relatively flexed body and a longish, raised tail at the end. A dog's image comes rarely without a tail, e.g.: from the Surmushi treasure (pl. I, fig. 8), from the Samtavro grave 121 (pl. I, fig. 11), with a triangle-shaped paws turned backward, e.g. Dgvaba, grave 2 (pl. I, fig. 9), from the Natsargora, grave 138 (pl. I, fig. 12), which sometimes resemble fish fin, e.g. Esheri pitcher, grave 4 (pl. I, fig. 3). The animal's eyes are indicated by a small dot e.g. on the accidentally discovered axe from Zakaani (pl. I, fig. 10), or are not indicated at all e.g. in Khikhadziri treasure (pl. I, fig. 1). Dog images are mostly decorated by lines composed of dots (pl. I, fig: 1, 3, 10), e.g. from the Sinatle treasure (pl. I, fig. 7), or by fish finlike ornaments, e.g. Tlia, grave 52 (pl. I, fig. 2), and sometimes - with circles, e.g. Khikhadziri treasure (pl. I, fig. 4), Oni (pl. I, fig. 5). Figures rarely come undecorated, e.g. from Surmushi treasure (pl. I, fig. 8). Together with the image of a dog, displayed images on axe include fish (pl. I, fig: 2, 3, 6), snake (pl. I, fig. 4), bird (pl. I, fig. 8) and deer (pl. I, fig. 19), as well as a graphic image of a human displayed on an axe discovered in Tlia burial ground grave 234 (Tekhov B. 1980: 14, 40, pl. 130, Fig. 2), the majority of axes are joined with a girdle decorated with different geometrical faces, e.g. Khikhadziri treasure (Kakhidze A. and Mamuladze Sh. 1993; 28, 34, pl. VI); Otkhara (Voronov Y. 1969: 19, pl. XXXV, 5); Achandara (Lukin L. 1941: 54-55, Fig. 5; Voronov Y. and Gunba M. 1978: 260, Fig. 3, 2; Trapsh M. 1970: 188, pl. X, 2); Zvandripshi (Trapsh M. 1970: 188, pl. X,3); Abgarkhuki (Voronov Y. and Voznuk A. 1975: 272273, Fig. 4]; Lailashi treasure (Domanski Y. 1984: Fig. 15); Tlia, grave 63 (Tekhov B. 1981: 9, 10, 12, 13, pl. 59, fig. 1, pl. 66, fig.1).

The dog images in the $1^{\text {st }}$ subgroup of group I are situated on the side surface of the axe (pl. I, fig: 1-12; 15-17), the poll (pl. I, fig: 2, 5, 19, 20, 21), axe-head, e.g. Tlia, grave 101 (Pl. I, fig. 23) and on the sides of the hole on the end-knob (Pl. I, fig. 2). Some axe cheeks display a dog, or a continuous line of joined dog heads over the girdle, e.g. Tsiteli Shukura, grave 94 (Pl. I, fig. 6). Figures of only dogs are displayed on the cheek, the poll and on the both sides of the end-knob hole of an axe discovered in Oni. The body of the same axe, up from the girdle are decorated with a line of joined dog heads (pl. I, fig. 5).

The images of dogs displayed on the poll (pl. I, fig. 21) and the cheek are more static (Pl. I, fig: $2,5,19-21)$, however more flexed figures are displayed by the end-knob hole, which must be stipulated by the rounded shape of the surface behind the image (Pl. I, fig. 19). The image of a dog with two legs on the poll can be provoked by the limited are for decoration, e.g. Okhureshi treasure([Koridze D. 1965: 34, pl. XLIV). A prevailing axe from the Tlia burial ground, grave 50 (p. I, fig. 20), displays a dog with four legs on the poll, however the image covers quite a large surface of the poll, where additional geometrical ornaments are not marked. We also have axes, where two-legged dogs are displayed on 


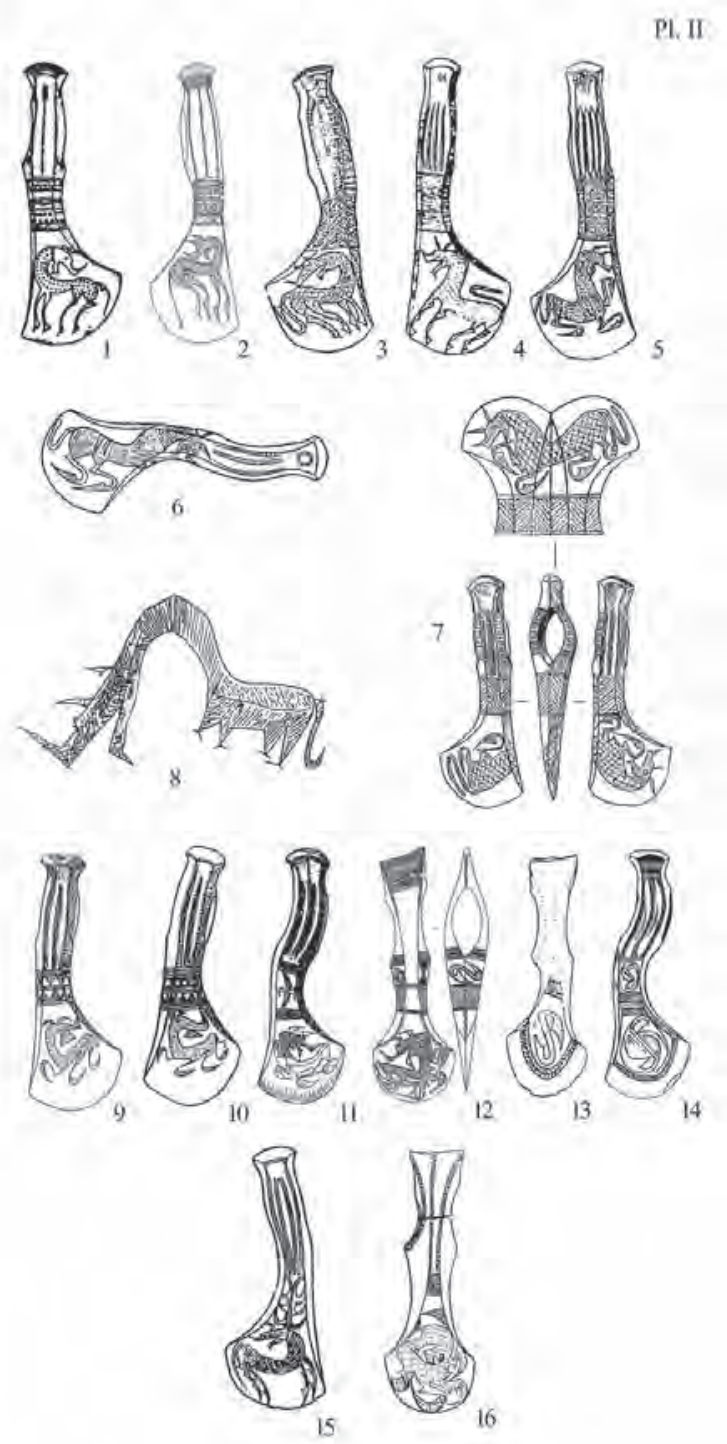

Pl. II - Second group:

1. Mzetamze, 7th-6th cc. BC (Nasidze G. 1990: 2, pl. IV,1); 2. Tskhinvali, hoard, 7 th-6 th cc BC (Pantskava L. 1988: 67; Japaridze Ot. 1950: pic.2c); 3. Tlia, grave 432, 7 th c. BC (Tekhov B. 2002: 50, pl. 104, fig. 1); 4. Tlia, grave 287, 7 th-6 th cc. BC (Pantskava L. 1988: 79; Tekhov B. 1980: 14, 46, pl. 117, fig. 1); 5. Tlia, grave 252, 7 th c. BC (Pantskava L. 1988: 69; Tekhov B. 1981: 14-15, pl. 72, fig. 1); 6. Tlia, grave 161, 7 th c. BC (Pantskava L. 1988: 71; Tekhov B. 1981: 38-39, pl. 111, fig. 1); 7. Tlia, grave 165, 8 th-7 th cc. BC (Pantskava L. 1988: 79; Tekhov B. 1980: 32-33, pl. 84, fig. 1); 8. Mzetamze, grave 4, 8 th-7 th cc BC (Georgien 2001: 347); 9. Tlia, grave 316, 7 th-6 th cc. BC (Tekhov B. 1985: 5, 51, pl. 200, fig. 1); 10. Tlia, grave 127, 7 th-6 th cc. BC (Pantskava L. 1988: 79; Tekhov B. 1981: 35, pl. 105, fig. 1); 11. Tlia, grave 374, 7 th c. BC (Tekhov B. 2002: 186-187, pl. 50, fig. 1); 12. Eshera, 7 th-6 th cc. BC (Voronov Y. and Gunba M. 1978: 163-264, pic. 6, fig. 2); 13. Mekhchistsikhe, hoard, 8th-6th cc. BC (Pantskava L. 1988: 70; Koridze 1965: 37-38, pic. 30, fig. 5); 14. Tskhinvali, hoard, 7 th-6 th cc BC (Pantskava L 1988: 67; Japaridze Ot. 1950: pic.2a); 15. Tsoisi, grave, 8th-6th cc. BC (Pantskava L. 1988: 58, pl. XIX, 3); 16. Khevi, grave, 7th c. BC (Pantskava L. 1988: 70; Koridze 1965, pl. XXXVI). 
the cheeks, e.g. Tlia burial ground, grave 414 (pl. 1, fig. 15), however the area for the image is rather reduced due to the geometrical ornamentation.

The $1^{\text {st }}$ group's $1^{\text {st }}$ subgroup unites the dog figures situated on a triangular area framed with ornaments, displayed on the side cheeks of type IV axes acquired from the Tlia burial ground, graves 160 (Tekhov B. 1980: 32, pl. 83, Fig. 1) and 234 (Tekhov B. 1980: 103, Fig. 2). The indicated images are somewhat stylized, however the natural-linear character of the artwork is still preserved. Engraved in the same manner are the two images of facing dogs, which have thin legs and are displayed standing on the decorative triangle arc with heads downward on the cheeks of an axe from Svaneti (pl. I, fig. 17). On the cheek of an axe discovered in the grave 53 in Narekvavi, fifteen dog figures aligned in six lines are displayed on a triangular surface decorated with a twisted spirals, engraved in a naturalistic manner (pl. I, fig. 16).

Images of dogs on certain axes are particularly stylized; however, they preserve the naturalistic characteristics at the same time. We have allocates such images to the $2^{\text {nd }}$ subgroup of group I, e.g. the end-knob and the cheek of an axe from Anukhva are decorated with an image of three dogs, out of which two are facing the poll, and the one displayed on the cheek is facing downward. This axe does not have a girdle (Pl. I, fig. 13). The dog images similarly facing downward displayed on the cheeks of axes from Eshera (Shamba G. 1984: 51, pic.15, fig. 2), Tasrakva (Voronov Y. 1969: 22-23, pl. XXXV, fig. 1) and Primorskoe (Kuftin B. 1949: 139, Fig. 24) are even more stylized. The have an elongated torso and disproportionally large heads. These axes do not have girdles either. Both axes belong to type I.

We have also included into the $2^{\text {nd }}$ subgroup of group I the type IV axes discovered on the Tlia burial ground, on which dog images are displayed in length. Their bodies are decorated with lines (Tekhov B. 2002: 185, pl. 15, fig. 1), twisted spirals (Tekhov B. 1981: 13, pl. 67, fig. 1) and voluminous circles (Pl. I, fig. 14). Some parts of these figures are stylized. The elongated torso is moderately curved, the animal's snout thickened, and the arced paws are fish finlike (Pl. I, fig. 14). The given axes do not have girdles either, however the poll is covered with fish, frog, snake and faces with circles beams.

The image of the dog is always well suited to the form of an axe, what can be well distin- guished on every section of its decorations. In this sense, remarkable is the axe from Eceri, which portrays aligned dog heads along the narrow line of axe's body (Pl. I, fig. 22) and the axe from the Tlia, grave 308, the decorated arc of which portrays a line of joined dog heads facing downward, matching the contour of the cutting edge (pl. I, fig. 18). Similar images can be found on axes from Tlia grave 263 (Tekhov B. 1981: 16-17, pl. 74, fig.1) and Erega 4, grave 2 (Mikeladze T. 1995: pl. 8, fig. 6). The heads of animals in profile are represented with mouths open and ears pricked up and the work is performed naturalistically, however the rhythmical repetition of the arced headnecks is so aggravated, that the aspiration towards ornamental work can be distinguished. According to these characteristics we have unified the items in the $2^{\text {nd }}$ subgroup of group I. Sometimes, the joined dog heads are substituted by geometrical ornaments with similar form and content, e.g. axe from Mukhurcha (pl. I, fig. 24).

The images allocated into group I are generally dated VIII-VII CC. B.C., some of them (pl. I, fig: $6,9,16,18,23$ ) - VII-VI CC. B.C. and are displayed on type I, II, IV and V axes (view the literature along with the description of plates).

The II group (pl. II, fig: 1-16) unifies dog images, which similar to the group I samples, are performed graphically, in profile, with pricked up ears and a tail lifted at the end, however this time with widely opened mouths, a thickened snout, pointed jaws and limbs. The majority of them have their heads twisted backwards; however the breastneck and torso are curved inward. A disproportional composure and the deformation of separate body sections or the whole figure is characteristics for these images. The geometricizing and the scheming of the image is present. This process began somewhat later than the images of group I and continued simultaneously with it, however in the final stage it gained superiority, even though by the end of the Colchis graphic art, the naturalistically performed works continued to exist.

A part of these rather stylized images become similar to the images of group I, sometimes due to their pose, or the modeling of different body parts. They more or less preserve the fair proportional and figurative character. We have unified such images of dogs into the 1st subgroup of group II. 


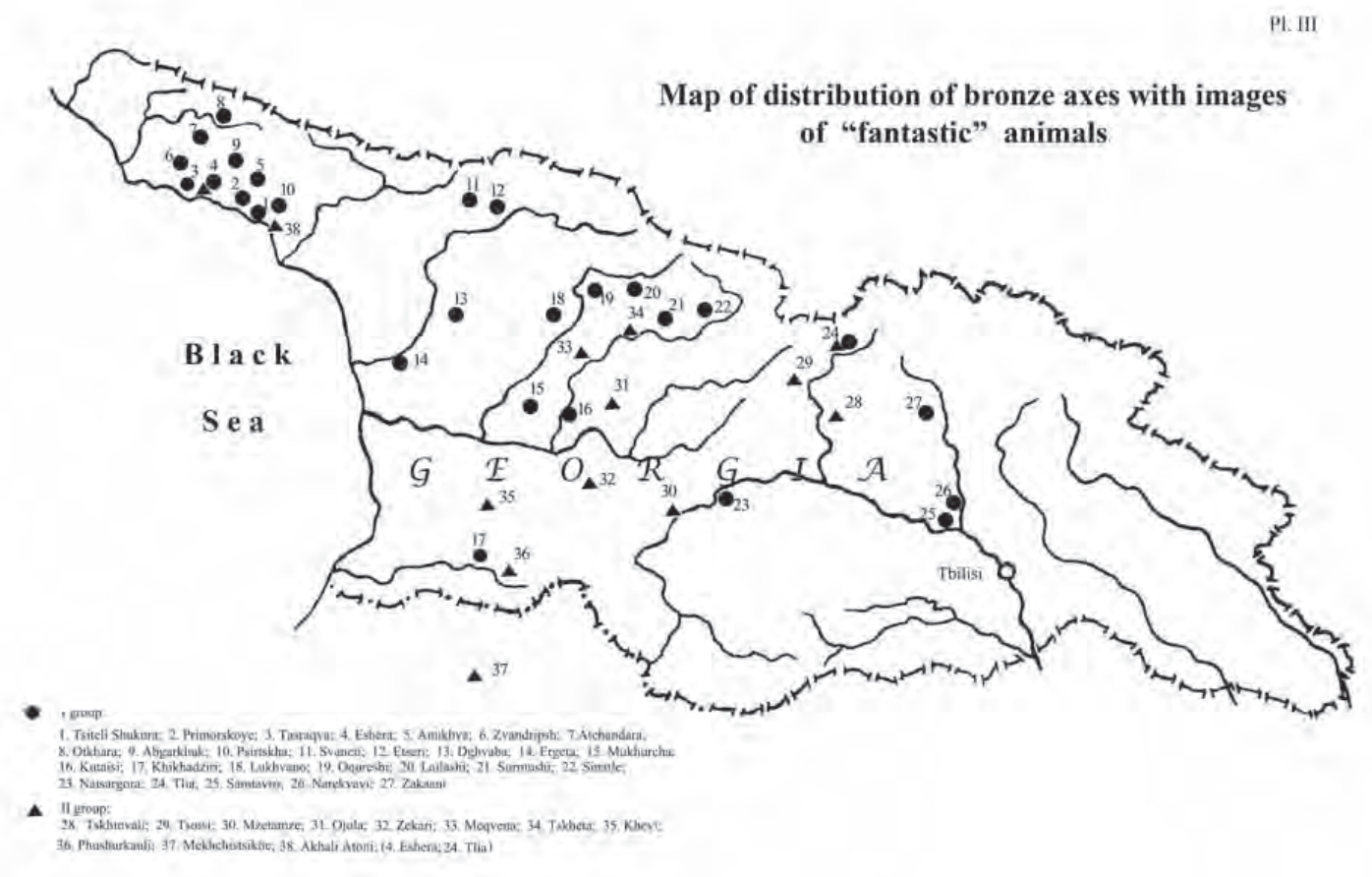

Pl. III - Map of distribution of bronze axes with images of "fantastic" animals.

We have unified the rather stylized images of dogs with widely opened mouths, a simplified pointed snout and ears, engraved on axes from the Tlia burial ground graves 161, 165, 287, 252 according to their general characteristics; however all of them are presented with their heads facing forward. The images of dogs displayed on items from graves 161, 165 (pl. II, fig: 6, 7) have a moderately curved torso and a head, which is proportionate to the body. However the heavily concaved body of the rather stylized dog figure, from grave 252 (pl. II, fig. 5), connects directly with the disproportionally large head, through a curved neck, which gives the composition a shape of S. The arced and turned paws of all three dogs end with pointed claws. The dog image of the grave 287 is rather proportional (pl. II, fig. 4), legs end with triangle-shaped paws, which makes them similar to the Mzetamze and Tlia, grave 432 images (pl. II, fig: 1, 3), and with its tail shape and the net-like decoration of the body, resembling dog images of the Tlia burial ground graves 165 (pl. II, fig. 7) and 432 (pl. II,fig. 3). All axes are of type II, and the ones from grave 161 are of type IV (pl. II, fig. 6). cal image of a fish (Tekhov B. 1980: 14, 44, pl. 114, fig. 1). The axes are of type II.

We have allocated to the 1st subgroup of group II, the engraved "dog" figure (pl. II, fig. 8) on the type I axe, which is similar to the images mentioned above due to its mouth cut, horn-like pointed aggravations on the lips, and the tail lifted at the back. The rectangular torso of the animal and short triangular legs are displayed on one side of the axe, and the long arched neck and a gigantic head - on the other side. The composition is completely geometricized and is made up of a rectangle, a triangle and an arch, however the image has not turned into a geometrical ornament, since the principle of submitting a particle to the whole is still present, therefore, the figurativeness of the image is preserved.

Other images in the $1^{\text {st }}$ subgroup of group II are displayed in: Ojola treasure (Koridze D. 1965: 38, Fig. 31), Tskheta (Koridze 1965: pic. 62, fig. 2), Tlia, grave 271 (Tekhov B. 1981: 17-18, pl. 77, fig. 1], Zekari [Ivashenko M. 1941: 7-8, Fig. 3 b).

Full stylization of dog images can be seen on Colchis axes, which come from different graves 
of the Tlia burial ground. We have allocated these types of images in the $2^{\text {nd }}$ subgroup of group II, e.g. images from the Tlia graves 316, 127 (pl. II, fig: $9,10)$. The complete destruction of proportions is characteristic to such images, as well as the scheming and geometricizing of the forms. A short torso is of the form of an arc and with a long arched neck connects to a head turned backward, which also has arched and pointed ears. A thickened snout ends with a bill pointed upward, however the lower jaw is trapeze-shaped. The limbs are thin lines, which end with smaller arcs. The tail is also displayed in the form of a short line, raised at the end. All images are dotted. The axes are of type II. Similar images can be found on axes from Tlia graves 49, 130 (Tekhov B. 1981: 30, 31, 35, 36, pl. 97, fig 1, pl. 106, fig. 1) and graves 121, 129 (Tekhov B. 1985: 17, 18, 20, pl. 128, fig. 1; pl. 131, fig. 1).

The stylization of dog images reaches its culmination in the figures displayed on Colchis axes, which are almost completely arched and leave the impression of infinitely turning circles at the first glance (pl. II, fig: 11, 12, 16). We have allocated them into the 3rd subgroup of group II. The maximal geometricizing and ornamentation of the form is evident: e.g. the images on the axes from Pushrukauli (Kakhidze A. and Mamuladze Sh. 1993: 3738, pl. IX) and Eshera (pl. II, fig. 12) burial ground coming from Khevi treasure (pl. II, fig. 12) have no characteristics of a dog left, and look more like geometrical ornaments. All axes are of type I, only one axe coming from the Tskinvali treasure (Japaridze Ot. 1950: 101-106, Fig. 2 b) is of type II and one more axe from the Tlia burial ground, grave 374 (pl. II, 11) is of type IV. Similar images are displayed on axes from Tlia grave 51 (Tekhov B. 1981: 7-8, pl. 53, fig. 2); grave 69 (Tekhov B. 1985: 5, 10, pl. 109, fig. 1); graves 362/1, 425, 462 (Tekhov B. 2002: 22, 192-193, 47, 61, pl. 32, fig. 1; pl. 100, fig. 1; pl. 127, fig. 6); from Akhali Atoni (Lukin A. 1941: 43, pl. VII, fig. 5).

We have allocated the geometrical-symbolic sign of a dog or a "fantastic" animal into the 4th subgroup of group II, which is twisted in the shape of eight, has two joined, pointed paws, which depict the conditionally marked animal, e.g. the image from Mekhchistsike treasure (pl. II, fig. 13). By reducing the whole composition to a single detail, the received symbolic image of an animal at the same time represents a geometrical ornamentation. We come across such geometrical-symbolic ornaments on the girdle of an axe (Tekhov B. 2002; 48-49, 187, pl. 102, fig. 1) or under the hole of the end-knob (pl. II, fig. 12). Similar images are displayed on axes in Tlia, graves 297 (Tekhov B. 1981: 48-49, pl.133, fig. 1), 76 (Pantskhava L. 1988: 67, pl. XV, fig. 2) and 417 (Tekhov B. 2002; 44, pl. 90, fig. 1). This symbolic sign can be only displayed on the cheek of the axe, e.g. Tlia grave 452 (Tekhov B. 2002; 57, pl. 123, fig. 1) or the cheek and the axe handle at the same time, e.g. there is such an axe from the Tskinvali treasure (pl. II, fig. 14). Two samples of similar axes come from Tlia, the cheeks of which are undecorated, however the mentioned symbolic sign is displayed on the handle, grave 391 (Tekhov B. 2002: 34, pl. 65, fig. 1) or situated under the hole on the end-knob, grave 345 (Tekhov B. 2002: 14, pl. 12, fig. 1). We come across symbolic signs on type I, II and IV axes.

Most dog images included in group II are dated VII-VI CC. B.C. and half of them are displayed on type I, II and IV axes and dated VIIIVII CC. B.C.

One part of the images displayed on Colchis axes is particularly remarkable. Extremely significant is the Tsoisi treasure axe (pl. II, fig. 15), on the cheek of which we come across branched out horns, however if observe closely, we'll find out that without horns, the animal is practically a dog (Pantskhava L. 1988: 43), it has a curved body typical of a dog, a head turned backward, a widely open mouth and pricked up triangular ears, bent forward, with which a deer is never portrayed. In the place of the second ear, deer horns are placed. Even more interesting is the fact that the animal has a long, slightly arched and straight-ended tail, typical of a horse, so atypical of a dog and a deer. In our opinion, in this case we are dealing with a synthesis of an image; where a unification of all three animals is represent (a dog, a deer, a horse).

On a certain development stage of the society, holy animals with similar functions like a dog, a deer and a horse are unified in one object. The image of the dog displayed on the axe from the Tsoisi treasure, as a creature connected to all three parts of cosmos, combines the characteristics of a horse and a deer, also connected to all three parts of cosmos, as a result we receive a syncretic animal object, which with its form, as well as its content already represents a "fantas- 
tic"animal. However, this tendency which moved from particular objects to syncretic does not end here. For example an extremely stylized and geometricized animal is displayed on the axe from the Khevi treasure. The object is a combination of almost all animals - birds and fish connected to the beliefs and imagination of the people (pl. II, fig. 16). The animal displayed on the cheek of the axe has a widely open mouth and pricked up triangular ears, fish-like fin and bird-like claws. The torso is decorated with a rhombus pattern net; however the one single hoofed foot is typical of horse. The same figure is transmitted through the unity of geometrical figures (arc, triangle, rectangle, circle), which makes up an abstract image of a polymorphic creature, which more looks like a geometrical ornament, rather than an animal. Apparently, the unified depicting of all three parts of cosmos animals, which implied the combination of characteristic signs of each one of them into a single figure, resulted in turning the image into a hybrid or "fantastic" animal, and heavy stylization and maximal geometricizing of the form turned out to be the most practical and expressive way to achieve this.

The main characteristics of Colchis axes decoration style of the wide mastery of iron and the late bronze-iron age, is the combined graphical display of animals (in this case a dog and a "fantasic" animal) and geometrical images. Dog images are always given in profile, with mouths open, ears pricked up and the end of the tail twisted upward. Geometrical images engraved in the same graphical style serve as the background for majority of these images, which adds decorative character to the image.

Regardless of the diversity and variety of the dogs and "fantastic" dogs unified in groups I and II, in this case we deal with a unified style of artistic thinking. Such representations with common stylistic signs make up one big and complete artistic group and never cross the boundaries of this single style.

The differences between the dog images in group I and II were caused not by the development and change of the style, but the work manner throughout time, which shifted from the naturalistic approach to the schematic stylization, from realistic images to abstract, surreal figures, from flexed forms to complete geometricizing, and from decorative - to ornamental character. Images portraying particular forms and content turned into syncretic and polymorphic figures, as a result of which, once a dog image acquired the image of a "fantastic"animal.

Such is the typology development of the "fantastic" animal in Georgia.

\section{BIBLIOGRAPHY}

\section{In Georgian:}

\section{Abramishvili R. 1957}

Samtavros samarovanze agmochenili gviani brinjaos xanisa da rkinis parto atvisebis xanis dzeglebis datarigebisatvis (For dating the monuments of the late bronze and the wide mastery of iron ages from Samtavro burial graund) // Moambe (National Georgian Museum Publication), XIX-A and XXI-B, (Tbilisi 1957), 115-140.

\section{Abramishvili R. 1961}

Rkinis atvisebis sakitkhisatvis agmosavlet Saqartvelos teritoriaze, (dzv. c. XIV-VI ss.) (Mastery of Iron issues on the territory of east Georgia (XIV-VI CC. B.C.)) //Moambe (National Georgian Museum Publication), XXII-B, (Tbilisi 1961), 291-379.

\section{Amiranashvili Sh. 1971}

Kartuli xelovnebis istoria (History of Georgian Art), (Tbilisi 1971).

Apakidze A., Nikolaishvili V., Kipiani G. Sikharulidze A., Giunashvili G., Gavasheli E., Glonti N., Kapanadze M. 2000

Narekvavis samarovani (Narekvavi burial ground) Mtskheta 1999, Narekvavi II, (Tbilisi 2000), 3-105.

Virsaladze E. 1964

Kartuli samonadireo eposi (Georgian Hunting Epos). (Tbilisi 1964).

Kakhidze A., Mamuladze Sh. 1993

Achariscklis kheobis udzvelesi arqeologiuri dzeglebi (Ancient archaeological monuments of the Acharistskhali valley). (Batumi 1993). 
Koridze D. 1965

Colchuri kulturis istoriisatvis (= For the History of Colchis Culture). (Tbilisi 1965).

\section{Lortkipanidze Ot. 2001}

Gandzebi kolxuri brinjaos kulturashi (funqciis, definiciisa da kulturul-sociologiuri interpreteciis cda) („Hoards” in Colchian Bronze Culture (An Attempt at Functional Definition and Sociological and Ethnocultural Interpretation)) //Dziebani (The Journal of the Centre for Archaeological Studies of the Georgian Academy of Sciences). Supplement. VI,. (Tbilisi. 2001), 178-194.

\section{Mikeladze T. 1974}

Dziebani Colchetisa da samkhret-agmosavlet shavizgvispiretis udzvelesi mosakhleobis istoriidan (Findings from the History of the Ancient Population of Colchis and the South-East of the Black Sea Coast).( Tbilisi 1974).

\section{Mikeladze T. 1985}

Colchetis adrerkinis khanis samarovnebi (Early Iron Age Burial Grounds of Colchis). (Tbilisi 1985).

\section{Nasidze G. 1990}

Colchuri kulturis axali kera (=The New Core of Colchis Culture). (Tbilisi 1990).

\section{Ramishvili A. 2003}

Gravirebuli Colchur culebiani samarkhi sofel Nacargoradan (Engraved Colchis Axes from the Burial Ground of Village Natsargora // Dziebani (The Journal of the Centre for Archaeological Studies of the Georgian Academy of Sciences), no. 12, (Tbilisi 2003), 41-48.

\section{Ramishvili K. 2010}

Colchur culebze gravirebuli „Fantastikuri cxovelis" gamosaxulebata tipologiisatvis (stilisa da kompoziciis gaazrebis cda) (= For the Typology of Engraved Defictions of "Fantastic Animals" on Colchis Axes, the Attempt of Analyzing the Style and Composition // Iberia-Colchis (Researches on the Archaelogy and History of Geargia in the Classical and Early Medieval period), no. 6, (Tbilisi 2010), 81-95.

\section{Ramishvili K. 2011}

„Fantastikuri cxovelis” gamosaxulebebi Cochuri kulturis mxatvruli khelosnobis dzeglebze (Representattions of „Fantastic Animal” on Artisan items of Colchis Culture // Dziebani (The journal of the Georgian Archaeology), no. 20, (Tbilisi 2011), 255-271.

\section{Sulava N. 2010}

Brinjaos nivtebze „Fantastikuri” cxovelebis gamosaxulebebis gavrcelebis Shesaxeb (On the diffusion of representations of "Fantastic" animals on bronze items // Dziebani (The journal of the Georgian Archaeology), no. 19, (Tbilisi 2010), 154-159.

\section{Sulava N., Ramishvili K. 2011}

Colchur-kobanur brinjaos nacarmze „fantastikuri” cxovelis gamosaxulebis qronologiisatvis (Towards the Chronology of the Representation of a "Fantastic” Animal on Colchian-Koban Bronze Items), Iberia-Colchis (Researches on the Archaelogy and History of Geargia in the Classical and Early Medieval period), no.7, Tbilisi 2011), 131-144.

\section{Pantskava L. 1988}

Colchuri kulturis mxatvruli khelosnobis dzeglebi (The Monuments of The Colchis Culture Artistic Workmanship. (Tbilisi 1988).

\section{Chartolani Sh. 1977}

Svanetis brinjaos xanis arqeologiuri dzeglebi (Bronze Age Archaeological Monuments of Svaneti. (Tbilisi 1965).

\section{Japaridze Ot. 1950}

Cochuri culi (A Colchis Axe) // Moambe (National Georgian Museum Publication), XVI-B,. (Tbilisi 1950), 35-89

\section{Japaridze Ot. 1950}

Tskhinvalis gandzi (Tskhinvali Treasure) // Moambe (National Georgian Museum Publication), XVI-B, (Tbilisi 1950), 99-107.

\section{In Russian:}

\section{Amiranashvili Sh. I. 1950}

Istoria gruzinskogo iskusstva, I (= History of Georgian Art, I. (Moscow 1950). 
Apakidze J. B. 1991

Centralnaia Kolxida v epoxu pozdnei bronzi-rannego jeleza (Central Colchis in the Late Bronze-Early Iron Age). (Tbilisi 1991).

\section{Bardavelidze V. V. 1957}

Drevneishie religioznie verovania I obriadovoe graficheskoe iskusstvo gruzinskix plemen (Ancient Religious Beliefs and Customs of Graphic Art of Georgian Tribes). (Tbilisi 1957).

\section{Voronov Y. N. 1969}

Arkheologicheskaia karta Abxazii (The Archaeological Map of Abkhazia). (Sokhumi 1969).

\section{Voronov Y. N., Voznyuk A. S. 1975}

Novie arkheologicheskie naxodki v Gudautskom raione Abxazskoi Avtonomnoi respublike (New Archaeological Findings in the Gudauta Region of the Abkhazian Avtonomous Republic) // Sovetckaia Arkheologia (Soviet archeology), no. 2, (Moscow 1975), 268-274.

\section{Voronov Y. N., Gunba M. M. 1978}

Novie pamiatniki Kolkhidskoi kulturi v Abxazii (New Monuments of the Colchis Culture in Abkhazia) // Sovetckaia Arkheologia (Soviet archeology), no. 2, pp. 257-264. (Moscow1978), 257-264.

\section{Domanski Y. V. 1984}

Drevnaia khudojestvennaia bronza Kavkaza v sobranii Gosudarstvennogo Ermitaja (Ancient Bronze Art of Caucasus in the Collection of the National Hermitage).(Moscow 1984).

\section{Ivashenko M. M. 1941}

Materiali k izucheniu kulturi Kolkhov (Materials for the Study of Colchis Culture // masalebi saqartvelosa da kavkasiis istoriisatvis (Materials for the History of Georgia and Caucasus), II Edition, (Tbilisi 1941), 1-66.

\section{Kuftin B. A. 1949}

Materiali k arkheologii Kolkhidy (Materials for the Colchis Archaeology), I, (Tbilisi 1949).

\section{Lukin A. L. 1941}

Materiali po arkheologii Bzipskoi Abkhazii (Materials for the Archaeology of Bzypsic Abkhazia) // The Works of Antecedent Culture in the History Di- vision of the Hermitage, I, (Leningrad 1941), 17-97.

\section{Meshaninov I. I. 1925}

Zmeia I sobaka na veshchevikh pamiatnikakh arkhaicheskogo Kavkaza (Snake and Dog Images on Material Monuments of Archaic Caucasus) // Zapiski Kollegii vostokovedov pri Akademii Muzeia Rossiiskoi Akademii Nauk (Notes of the Board of Orientalists of the Academy of the Museum of Russian Academy of Sciences), I, (Leningrad 1925), 241-256

Mikeladze T. K., Migdisova N.P., Papuashvili R.P., Chubinishvili N. T. 1995

Kolkhidskaia Ekspedicia (Colchis Expedition) // Polevie Arkheologicheskie Issledovania (Field Archeological explorations), (Tbilisi 1995), 39-43.

\section{Miller A.A. 1922}

Izobrajenie sobaki v drevnostiakh Kavkaza (Images of a Dog in Ancient Caucasus) // Izvestia Rossiiskoi Akademii Istorii Materialnoi Kulturi (Findings of the Russian Academy of History of Material Culture), II, (Peterburg 1922). 287-324.

\section{Tekhov B. V. 1980}

Tliiskii mogilnik, I (The Tlia burial ground, I), (Tbilisi 1980).

Tekhov B. V. 1981

Tliiskii mogilnik, II (The Tlia burial ground, II), (Tbilisi 1981).

\section{Tekhov B. V. 1985}

Tliiskii mogilnik, III (The Tlia burial ground, III), (Tbilisi 1985).

\section{Tekhov B. V. 2002}

Taini drevnikh pogrebenii (The Secrets of old Burials). (Vladicaucasus 2002).

\section{Trapsh M. M. 1970}

Pamiatniki epokhi bronzi I rannego jeleza v Abxazii, Trudi I (The Monuments of the Bronze and Early Iron Ages in Abkhazia), Works I (Sukhumi 1970).

Trapsh M. M. 1969

Drevni Sukhumi, Trudi II (Ancient Sokhumi). Works II. (Sokhumi 1969). 
Uvarova P. S. 1900

Mogilniki Severnogo Kavkaza (Burial Grounds of the Northern Caucasus) // Materiali po arkheologii Kavkaza (Meterial towards the Archaeology of Caucasus), VIII. (Moscow 1900).

\section{Urushadze N. E. 1988}

Drevnegruzinskoe plasticheskoe iskusstvo (Ancient Georgian Plastic Art). (Tbilisi 1988).

\section{Shamba G. K. 1984}

Rasskopki drevnix pamiatnikov Abkhazii (Excavations of Ancient Monuments of Abkhazia). (Sokhumi 1984).

\section{In German:}

\section{Georgien 2001}

Schätze aus dem Land des goldenen Vlies (Treasures from the Land of the Golden Fleece). (Bohum 2001).

\section{Mikeladze T. 1995}

Grosse kollektive Grabgruben der fruhen Eisenzeit in Kolchis (Big collective grave pits the early Iron Age in Colchis) //Archäologischer Anzeiger (Archaeological Bulletin), (Berlin, New-York 1995).

\section{Unterwegs zum goldenen Vlies 1995}

(Heading to the Goldenen Fleece) (Saarbrüken 1995).

\section{REZIME}

\section{TIPOLOGIJA UGRAVIRANIH PREDSTAVA "FANTASTIČNIH" ŽIVOTINJA NA KOLHIDSKIM SEKIRAMA}

Ključne reči: kolhidske sekire, kolhidsko-kobanska bronza, fantastična životinja.

Jedan od važnih elemenata u dekoraciji kolhidske bronze je prikaz psa ili fantastičnih životinja. Ugravirane predstave psa na kolhidskim sekirama pronađenim u Gruziji mogu se podeliti u dve grupe. Prvu grupu čine primerci koji su rađeni više naturalistički, linearnim načinom. Druga grupa nalaza je rađena vrlo stilizovano i šematski. Ukrašene sekire sadrže najčešće predstave psa i geometrijske motive. Psi su predstavljeni u profilu, sa otvorenim čeljustima i podignutim ušima i repom. Uprkos izvesnim varijacijama sve ove predstave formiraju stilsku grupu sa specifičnim karakteristikama.

Promene u načinu prikazivanja psa dovele su tokom vremena do formiranja novog stila koji je u prikazivanju išao od naturalističkog ka šematizaciji, od realističkog ka geometrijskom, od dekorativnog ka ornamentalnom. Prikazi konkretnih oblika su zamenjeni polimorfnim figurama, a predstava psa je transformisana u fantastičnu životinju. 